\title{
A new validated stability-indicating RP- HPLC method for simultaneous quantification of dolutegravir and lamivudine in bulk and pharmaceutical dosage form
}

\author{
Khaleel Noorbasha ${ }^{1 *}$ (i) and Sharmila Nurbhasha ${ }^{2}$
}

\begin{abstract}
Background: A fresh selective, rapid, accurate, precise and RP-HPLC stability-indicating method was developed and validated for the quantitative simultaneous determination of dolutegravir and lamivudine in the bulk as well as pharmaceutical dosage form. A chromatographic separation was done by using Inertsil ODS $3 \mathrm{~V}(250 \times 4.6 \mathrm{~mm}$, $5 \mu \mathrm{m})$ column and mobile phase composed of phosphate buffer, $\mathrm{pH}$ 3.0:acetonitrile:methanol (50:20:30\% v/v/v) with flow rate of $1.0 \mathrm{~mL} / \mathrm{min}$, and the detection of eluents was carried out at a wavelength of $257 \mathrm{~nm}$ utilizing a PDA detector. The drugs, dolutegravir and lamivudine, were subjected to varied conditions like base hydrolysis, acid hydrolysis, oxidation, thermal, photochemical and UV. The suggested method was analysed statistically and validated to fulfil requirements of International Conference on Harmonisation $(\mathrm{ICH})$ and the validation covered accuracy, precision, linearity, limit of detection (LOD), limit of quantification (LOQ), robustness, ruggedness and specificity.
\end{abstract}

Results: The retention time of dolutegravir and lamivudine were observed to be 6.36 and 2.16 min, respectively. The method was found to be linear within the range of 14.98 to $91.25 \mu \mathrm{g} / \mathrm{mL}$ for lamivudine and 2.54 to $15.35 \mu \mathrm{g} /$ $\mathrm{mL}$ for dolutegravir. The percentage recoveries (accuracy) for dolutegravir and lamivudine were in the range of 98.35 to $102.14 \%$ and 98.01 to $101.5 \%$. The computed relative variance (\%RSD) was within the suitable criterion of less than 2.0.

Conclusion: The suggested method was set to be precise as well as stability-indicating since no interfering degradant peaks and excipients were evident. All the peaks of degradation were successfully resolved by the use of the developed analytical method with altered retention times. Results obtained were analysed statistically and found to be acceptable in line with the ICH guidelines. Hence, such method is often employed successfully for routine analysis of active analytes in the bulk as well as pharmaceutical dosage form. It is going to be extended to review for its estimation in plasma and other biological fluids and may even be employed for quality control stability sample estimation and in cleaning method analysis during cleaning validation.

Keywords: Dolutegravir, Lamivudine, RP-HPLC, Acetonitrile, Methanol, Buffer

\footnotetext{
* Correspondence: khaleelnoorbasha@gmail.com

1 Department of Pharmaceutical Sciences, Acharya Nagarjuna University,

Nagarjunanagar, Guntur, Andhra Pradesh 522510, India

Full list of author information is available at the end of the article
}

\section{Springer Open}

( ) The Author(s). 2020 Open Access This article is licensed under a Creative Commons Attribution 4.0 International License, which permits use, sharing, adaptation, distribution and reproduction in any medium or format, as long as you give appropriate credit to the original author(s) and the source, provide a link to the Creative Commons licence, and indicate if changes were made. The images or other third party material in this article are included in the article's Creative Commons licence, unless indicated otherwise in a credit line to the material. If material is not included in the article's Creative Commons licence and your intended use is not permitted by statutory regulation or exceeds the permitted use, you will need to obtain permission directly from the copyright holder. To view a copy of this licence, visit http://creativecommons.org/licenses/by/4.0/. 


\section{Background}

Lamivudine [1] (Fig. 1) (LAM) has activity against human immunodeficiency virus type I (HIV-I) as well as hepatitis $\mathrm{B}$ and may be a nucleoside reverse transcriptase inhibitor (NRTI). Dolutegravir [2] (Fig. 2) (DOL) may be a novel HIV-1 integrase inhibitor which acts by binding to site and blocking strand transfer step to retroviral integration of DNA. It is often an important phase of HIV replication cycle and can end in the viral activity inhibition. It is given in combination with novel drugs such as lamivudine, dolutegravir and lots of other drugs. As this drug is approved by FDA and made by GSK Healthcare, it is marketed as Dovato, a hard and fast dose combination product containing dolutegravir and lamivudine. Chemically, dolutegravir is (3S,7R)- $\mathrm{N}$-[(2,4-difluorophenyl)methyl]-11-hydroxy-7-methyl-9,12-dioxo-4-oxa-1,8diazatricyclotetradeca-10,13-diene-13-carboxamide.

Lamivudine is (2R,cis)-4-amino-1-(2-hydroxymethyl-1,3oxathiolan-5-yl)-(1H)-pyrimidin-2-one. These medications are available in the market and prescribed either individually or as a combination form.

Dolutegravir and lamivudine (Dovato), manufactured by GSK Healthcare, may be a combination antiretroviral agent approved by the FDA as an entire regimen for HIV-1 infection treatment in case of adults. It is a fixeddose combination product consisting of dolutegravir 50 $\mathrm{mg}$ and lamivudine $300 \mathrm{mg}$. The recommended dose of the drug is once daily per oral with or without food in case of adults [3]. Dolutegravir, being an integrase strand transfer inhibitor, blocks replication of HIV by the amalgamation prevention of viral DNA into the host human immune T cells' genetic material [4]. In the pharmaceutical industry, an effective analytical method is needed to analyse a drug individually or simultaneously in combination with other drugs. Various methods of analysis were employed for quantitative determination of individual or

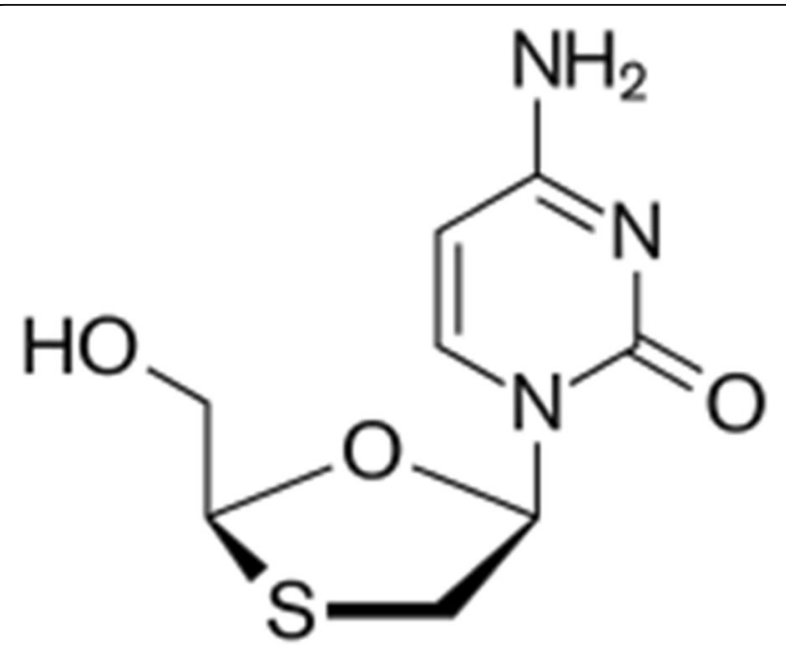

Fig. 1 Chemical Structure of lamivudine<smiles>C[C@H]1CCO[C@H]2Cn3cc(C(=O)NCc4ccc(F)cc4F)c(=O)c(O)c3C(=O)N12</smiles>

Fig. 2 Chemical Structure of dolutegravir

multi-component combination assay of nucleoside polymerase inhibitor (NPI) in pharmaceutical dosage forms. Various HPLC [5-14], LC/MS/MS [15-19], HPTLC [20, 21], UV [22-24] and UPLC [25] assay methods were described within the literature regarding the estimation of lamivudine, abacavir, and a few other anti-retroviral drugs individually as well as in combination with other drugs. On the converse based on the review of literature, no official method for the stability-indicating simultaneous estimation of dolutegravir and lamivudine by RPHPLC in the bulk and tablet dosage form was performed so far. Hence, there is an undertaken effort for research that has been made to develop and validate a novel and simple analytical method for the stability-indicating simultaneous estimation of dolutegravir and lamivudine in the bulk and pharmaceutical dosage form. The proposed novel method is able to separate all the active analytes present in the pharmaceutical dosage form and validated as per the guidelines of ICH (Q2 specification) [26].

\section{Methods \\ Materials}

Dolutegravir and lamivudine were received as gift samples from Mylan Laboratories Limited, Hyderabad, India. The marketed pharmaceutical tablets of Dovato consisting of dolutegravir $50 \mathrm{mg}$ and lamivudine $300 \mathrm{mg}$, respectively (manufactured by GSK Healthcare), were procured from the pharmacy. HPLC grade methanol, acetonitrile, Milli-Q water, orthophosphoric acid and analytical grade chemicals of sodium hydroxide, potassium dihydrogen phosphate, hydrogen peroxide and hydrochloric acid were purchased from Merck India Limited, Mumbai, India.

\section{Instrumentation}

HPLC-Waters alliance (Model-2695) was used to perform chromatographic separation which consists of a column oven, an in-built auto sampler and 2996 PDA detector. The information was obtained through the use of Empower-3-software. The column utilised was Inertsil ODS $250 \times 4.6 \mathrm{~mm}, 5 \mu \mathrm{m}$. Meltronics sonicator was used to enhance the solubility of the drugs. For $\mathrm{pH}$ 


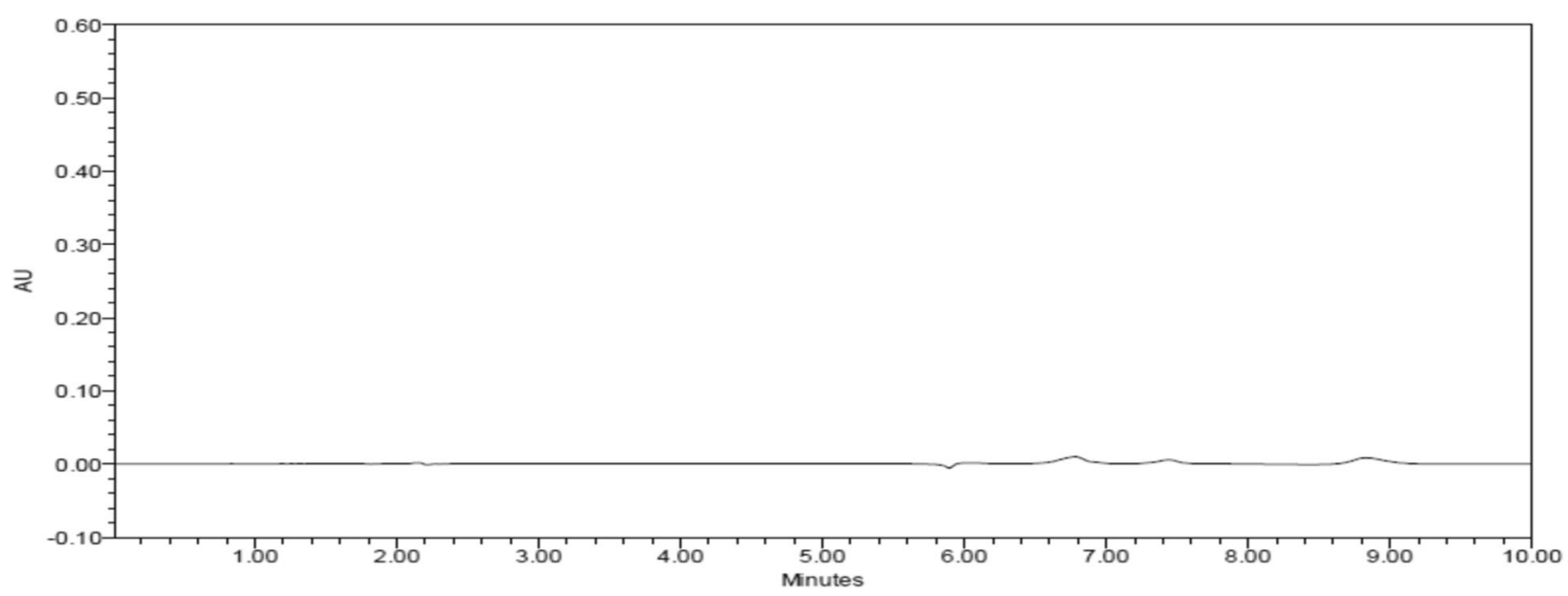

Fig. 3 Typical chromatogram of placebo

adjustment of the solution, Elico $\mathrm{pH}$ meter was employed. Sartorius balance was employed for weighing the samples.

\section{Optimised chromatographic conditions}

A chromatographic separation was achieved by using Inertsil ODS $3 \mathrm{~V}, 5 \mu \mathrm{m}$ particle size, $250 \times 4.6 \mathrm{~mm}$ column as a stationary phase and mobile phase composed of phosphate buffer, $\mathrm{pH}$ 3.0:acetonitrile:methanol (50:20: $30 \% \mathrm{v} / \mathrm{v} / \mathrm{v}$ ) with a flow rate of $1.0 \mathrm{~mL} / \mathrm{min}$, and the eluents were detected at a wavelength of $257 \mathrm{~nm}$ utilising PDA detector. The HPLC system was operated at $30{ }^{\circ} \mathrm{C}$ and therefore the runtime was $10 \mathrm{~min}$. Mode of separation was isocratic.

\section{Phosphate buffer solution, $\mathrm{pH} 3.0$ preparation}

$1.36 \mathrm{~g}$ of accurately weighed potassium dihydrogen orthophosphate was dissolved in $900 \mathrm{~mL}$ of HPLC grade water and the $\mathrm{pH}$ of the solution was adjusted to 3.0 with the addition of dilute phosphoric acid. Further, the volume was adjusted to $1000 \mathrm{~mL}$ with water and the prepared solution was filtered through $0.45 \mu \mathrm{m}$ membrane filter and degassed to sonicate.

\section{Preparation of mobile phase}

Phosphate buffer solution pH3.0, acetonitrile and methanol were taken within the ratio of 50:20:30\% v/v/v.

\section{Preparation of diluent}

The prepared mobile phase was used as diluent.

\section{Standard solution preparation}

Ten milligrammes of each dolutegravir and lamivudine working standards was weighed accurately and transferred into an individual 10-mL clean and dry volumetric flasks. Half volume of methanol was added and then the

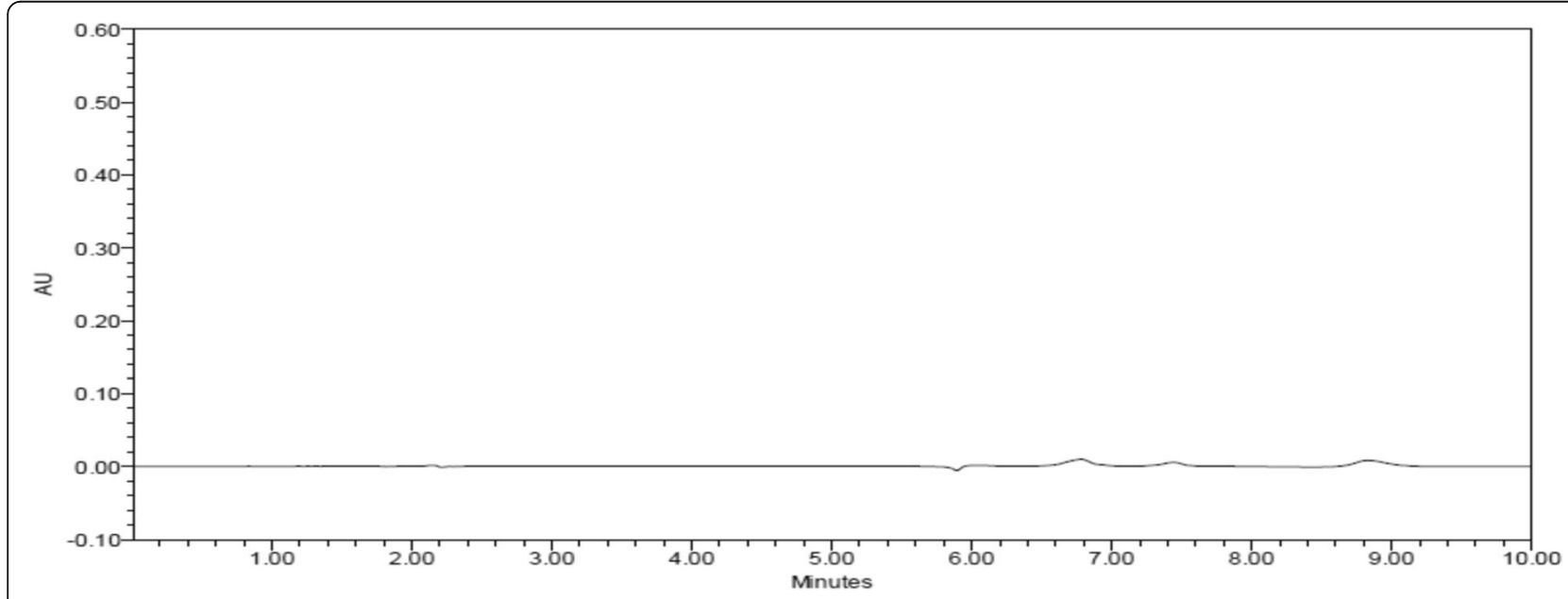

Fig. 4 Typical chromatogram of blank 


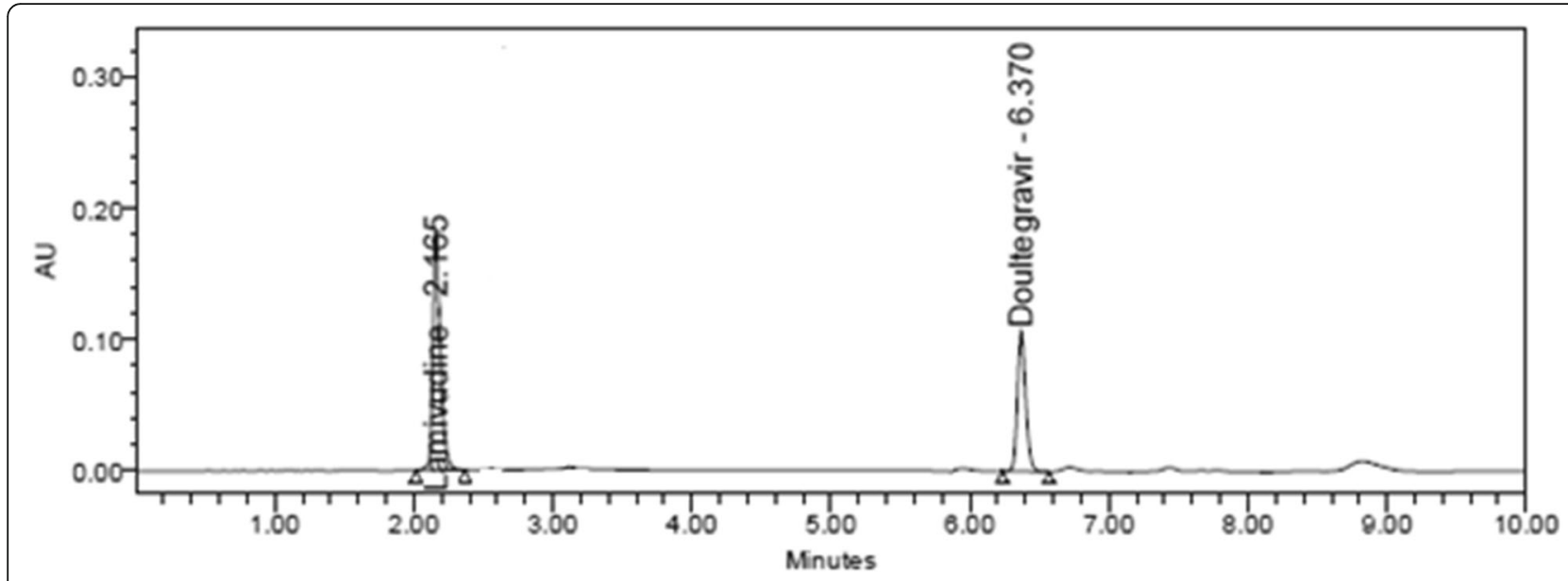

Fig. 5 Typical chromatogram of sample

volume was made up to the mark with diluent. $0.6 \mathrm{~mL}$ of lamivudine standard stock solution and $0.1 \mathrm{~mL}$ of dolutegravir standard stock solution were transferred into a $10-\mathrm{mL}$ volumetric flask and the volume was made up to the mark with the diluent to get a standard solution containing $60 \mu \mathrm{g} / \mathrm{mL}$ of lamivudine and $10 \mu \mathrm{g} / \mathrm{mL}$ of dolutegravir.

\section{Preparation of sample solution}

Twenty tablets were weighed and the average weight of each tablet was calculated. Then a quantity of powder equivalent to one tablet was weighed and transferred into a volumetric flask $(100 \mathrm{~mL})$, followed by addition of 3/4th volume of diluent and sonicated for half-hour. Further, the volume was made up with the diluent and filtered through $0.45 \mu \mathrm{m}$ filter. $0.5 \mathrm{~mL}$ of the above solution was transferred into a $25-\mathrm{mL}$ volumetric flask, and the volume was made up to the mark with the diluent and mixed up well to get a sample solution containing $10 \mu \mathrm{g} / \mathrm{mL}$ of dolutegravir and $60 \mu \mathrm{g} / \mathrm{mL}$ of lamivudine.

\section{Method validation}

The developed method was validated according to the ICH guidelines with reference to accuracy, precision, system suitability, specificity, linearity, limit of

Table 1 Results of system suitability

\begin{tabular}{llll}
\hline $\begin{array}{l}\text { Parameters for system } \\
\text { suitability }\end{array}$ & \multicolumn{2}{l}{ Result } & \multirow{2}{*}{$\begin{array}{l}\text { Acceptance } \\
\text { criteria }\end{array}$} \\
\cline { 2 - 3 } & LAM & DOL & \\
\hline $\begin{array}{l}\text { Retention time } \\
\text { \%RSD for area count of } 6\end{array}$ & 0.169 & 6.367 & For information \\
$\begin{array}{l}\text { standard replicate injections } \\
\text { Tailing factor }\end{array}$ & 1.34 & 0.8 & NMT 2.0 \\
$\begin{array}{l}\text { Theoretical plates } \\
\text { Resolution }\end{array}$ & 7643 & 55924 & NLT 2000 \\
\hline
\end{tabular}

quantification, limit of detection and forced degradation studies [26].

\section{System suitability}

The system suitability was checked by the use of 6 replicate injections of freshly made standard solution. The perceived RSD values were within suitable limits ( $\leq$ $2.0 \%)$. Theoretical plates, resolution and tailing factor of dolutegravir and lamivudine were determined and originated to be well within the suitable limits.

\section{Linearity}

The linearity was performed for the prepared standard solutions of dolutegravir and lamivudine at various concentration levels, i.e. within a range of 14.98 to $91.25 \mu \mathrm{g} /$ $\mathrm{mL}$ for lamivudine and 2.54 to $15.35 \mu \mathrm{g} / \mathrm{mL}$ for dolutegravir. Each measurement was administered in triplicate. The linearity was proven by multivariate analysis by least square method.

\section{Precision}

The precision of the method was demonstrated by intraday and inter-day analysis. The concentration used for the precision studies was assumed as $100 \%(10 \mu \mathrm{g} / \mathrm{mL}$ for dolutegravir and $60 \mu \mathrm{g} / \mathrm{mL}$ for lamivudine). To review the intra-day precision, the analysis of drugs was repeated sixfold on the similar day, and for inter-day precision, the analysis of drugs was made for six

Table 2 Results of linearity study

\begin{tabular}{lllll}
\hline S.No. & $\begin{array}{l}\text { Analyte } \\
\text { name }\end{array}$ & $\begin{array}{l}\text { Linearity range } \\
(\mu \mathrm{g} / \mathrm{mL})\end{array}$ & $\begin{array}{l}\text { Calibration } \\
\text { curve equation }\end{array}$ & $\begin{array}{l}\text { Correlation } \\
\text { coefficient }\end{array}$ \\
\hline 1 & Lamivudine & $14.98-91.25$ & $\begin{array}{l}y=11,326.640 x+ \\
5694.835\end{array}$ & 0.999 \\
2 & Dolutegravir & $2.54-15.35$ & $\begin{array}{l}y=49,345.031 x- \\
1016.567\end{array}$ & 0.999 \\
& & & &
\end{tabular}




\section{Linearity Plot of Lamivudine}

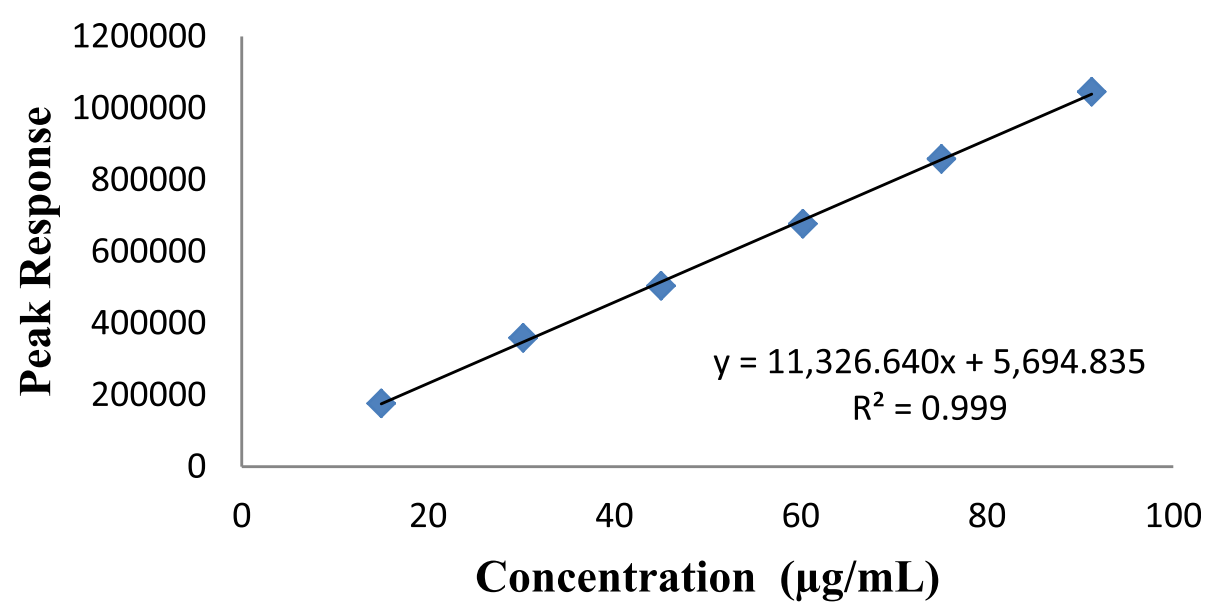

Fig. 6 Linearity plot of lamivudine

consecutive days for a concentration of $10 \mu \mathrm{g} / \mathrm{mL}$ for dolutegravir and $60 \mu \mathrm{g} / \mathrm{mL}$ for lamivudine.

\section{Accuracy}

For the determination of accuracy in the sample preparation method of the standard pattern, additions were done for the measurement of the recovery of drugs. A quantity of sample was taken and the standard drug was added at the levels of 50, 100 and $150 \%$. The results obtained were analysed and observed to be within bounds.

\section{Ruggedness}

The ruggedness of the method was confirmed by analysing the sample by various analysts on various instruments on various days.

\section{Robustness}

The robustness was determined by varying three parameters from the optimised conditions of chromatography like mobile phase composition $( \pm 5 \%)$, making small changes in the flow rate $( \pm 0.1 \mathrm{~mL} / \mathrm{min})$ and column temperature $\left( \pm 5^{\circ} \mathrm{C}\right)$.

\section{Limit of detection and limit of quantification (LOD and} LOQ)

LOD and LOQ were computed with the use of waters Empower software for signal-to-noise ratio method.

\section{Specificity}

The specificity of the method was carried out by the injection of a blank solution (i.e. without any sample), followed by injection of $10 \mu \mathrm{L}$ drug solution into the column under the optimised conditions of chromatography, in order to demonstrate the separation of two drugs

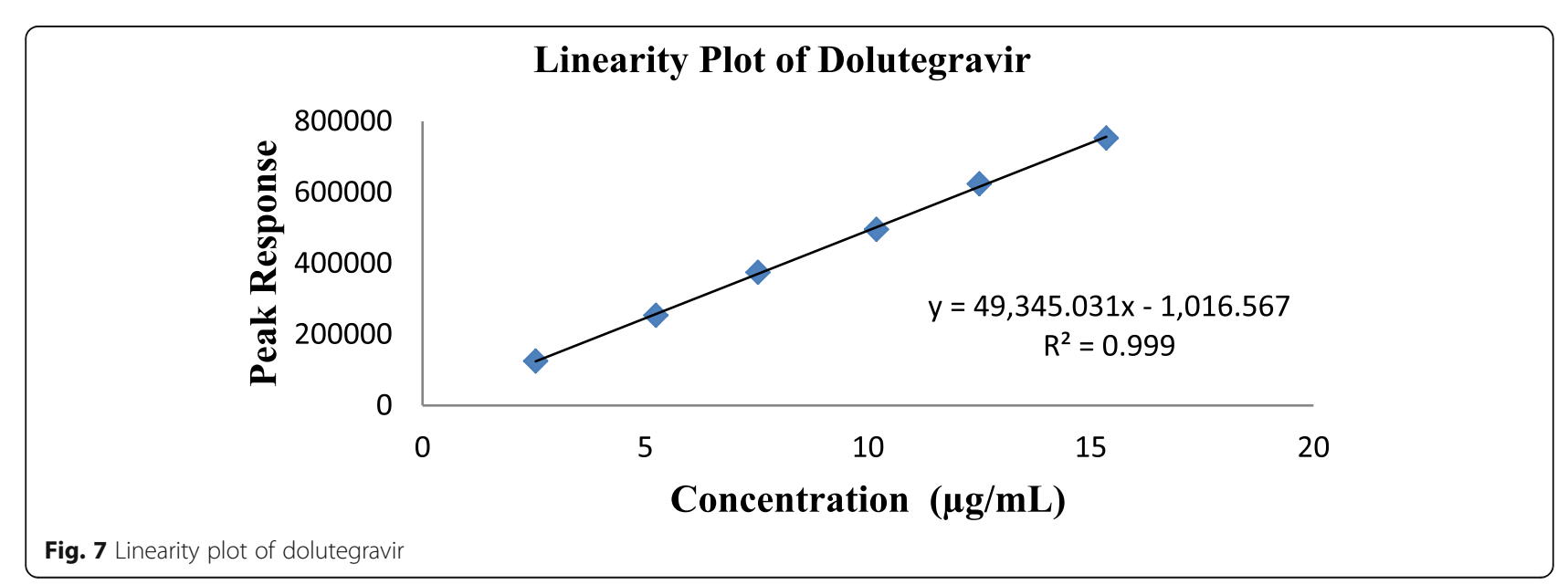


Table $\mathbf{3}$ Limit of detection and limit of quantification

\begin{tabular}{llll}
\hline S.No. & $\begin{array}{l}\text { Analyte } \\
\text { name }\end{array}$ & \multicolumn{2}{l}{ Obtained concentration values $(\mu \mathrm{g} / \mathrm{mL})$} \\
\cline { 3 - 4 } & LOD & LOQ \\
\hline 1 & Lamivudine & 0.40 & 0.88 \\
2 & Dolutegravir & 0.04 & 0.11 \\
\hline
\end{tabular}

dolutegravir and lamivudine from impurities present, if any.

\section{Forced degradation studies}

Such studies were carried out in order to demonstrate the optimised stability-indicating method and to find out if the method is able to quantify active pharmaceutical ingredient (API) accurately in the presence of degradation products that might be formed during various kinds of degradations pertained to drug sample. $\mathrm{ICH}$ guidelines (Q1A, Q1B, Q2B) highlight particular degradation environments such as base, acid, oxidation, photo and thermal stability.

\section{Results}

Development of RP-HPLC method

Suitable method was selected based on the character of the sample (neutral or ionic molecule), its relative molecular mass and solubility. Various conditions of chromatography were applied for the analysis of dolutegravir and lamivudine in both the bulk and pharmaceutical dosage form. The result of the analysis was within the suitable limit (not less than 2.0). Figs 3, 4 and 5 represent the chromatograms of placebo, blank and sample, respectively. This is often a sign of the specificity of developed RP-HPLC method.

\section{System suitability}

It was decided by making six replicate injections from the freshly made standard solutions. The RSD values were observed to be within the generally acceptable limit $(\leq 2.0 \%)$. Theoretical plates, resolution and tailing factor of dolutegravir and lamivudine were determined and located to be within the suitable limits as shown in Table 1.

\section{Linearity, limit of detection and limit of quantification}

The test for linearity was performed by making standard solutions of dolutegravir and lamivudine at various concentration levels, i.e. in a range of 14.98 to $91.25 \mu \mathrm{g} / \mathrm{mL}$ for lamivudine and 2.54 to $15.35 \mu \mathrm{g} / \mathrm{mL}$ for dolutegravir. Each measurement was administered in triplicate. The linearity was proven by multivariate analysis by least square method. The results show that a linear relationship exists between peak area and concentration of drugs within the given range as shown in Table 2 and Figs. 6 and 7.

LOD and LOQ were observed to be 0.40 and $0.88 \mu \mathrm{g} /$ $\mathrm{mL}$, respectively, for lamivudine and 0.04 and $0.11 \mu \mathrm{g} /$ $\mathrm{mL}$, respectively, for dolutegravir. Signal-to-noise ratio values for LOD and LOQ were found to be 3.3 and 10.2 for lamivudine and 3.1 and 9.7 for dolutegravir and observed all the obtained results were found to be within acceptance criteria according to the guidelines of $\mathrm{ICH}$ and the results obtained were as shown in Table 3.

\section{Recovery, precision and accuracy}

Within-day precision and accuracy of the method were analyzed from replicate analysis $(n=6)$. Precision of the method was finalised by intra-day and inter-day analysis. The percentage relative variance (\%RSD) was computed and was within the suitable criterion of $<2.0$. Accuracy was represented as the percentage of the respective active analyte recovery and also plotted linearity graph (Figs. 8 and 9) between the typical amounts added and the average amount recovered for all the active analytes and located to be linear for all the concentration levels (Tables 4, 5 and 6).

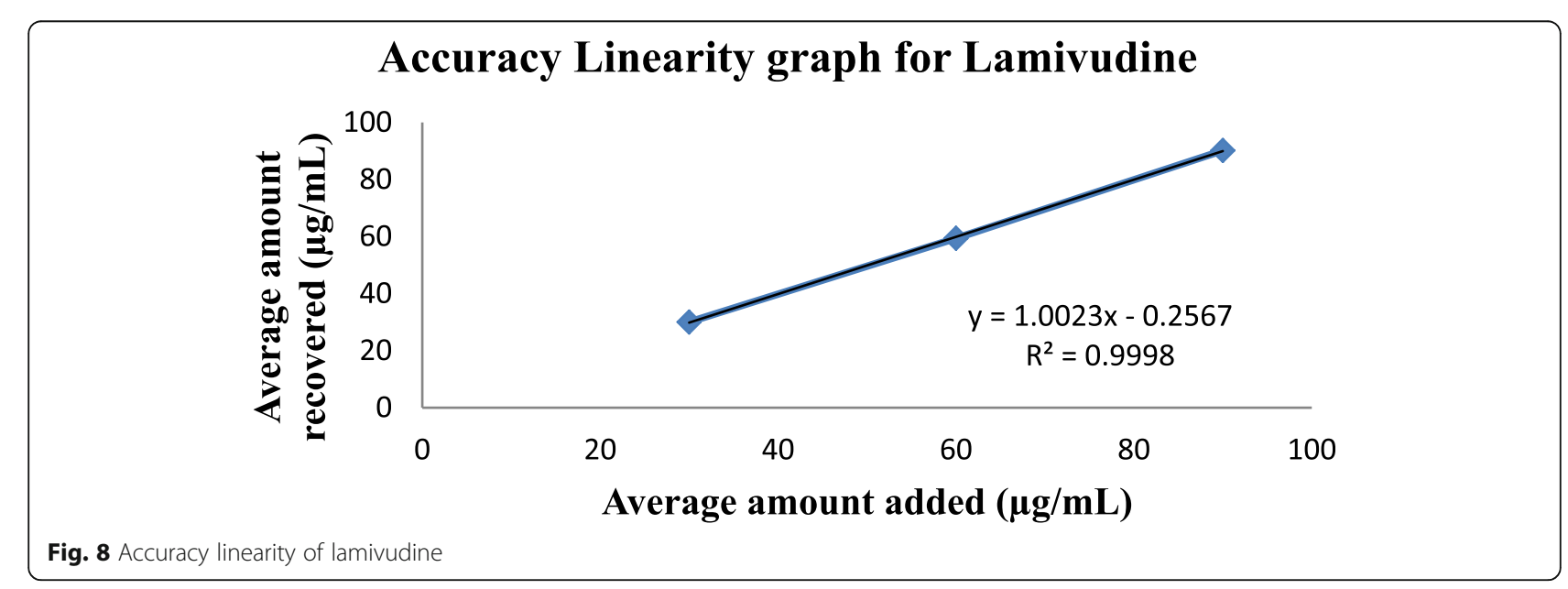




\section{Accuracy Linearity graph for Dolutegravir}

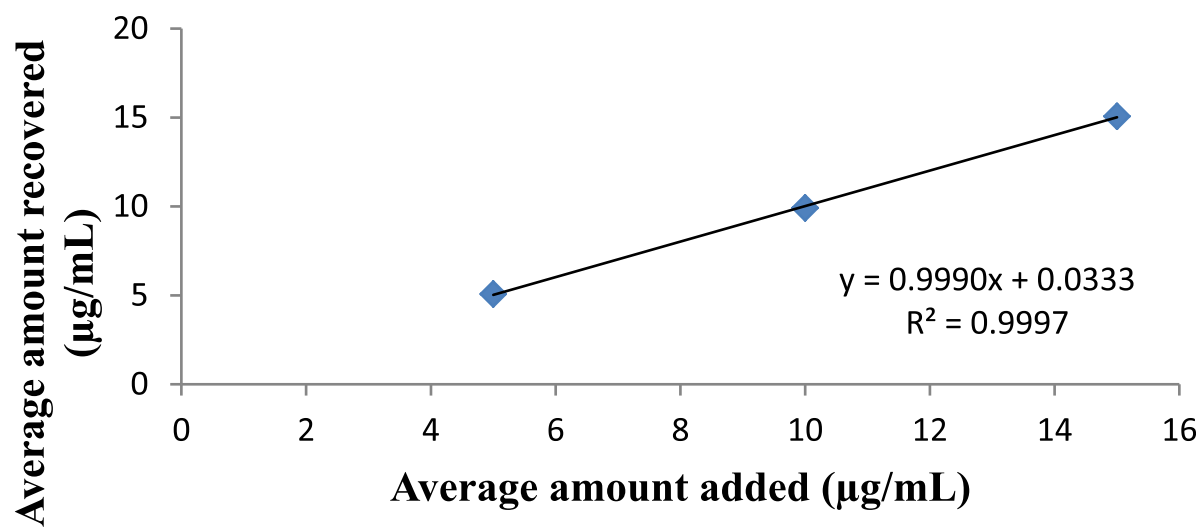

Fig. 9 Accuracy linearity of dolutegravir

\section{Ruggedness}

The ruggedness of the method was confirmed by the analysis of sample by various analysts on various instruments on various days. The results in Table 7 show that there were no significant changes within the chromatograms, which means that the developed RP-HPLC method is rugged in nature.

\section{Robustness}

The robustness was determined by varying three parameters from the optimised conditions of chromatography like mobile phase composition $( \pm 5 \%)$, making small changes in flow rate $( \pm 0.1 \mathrm{~mL} / \mathrm{min})$ and column temperature $\left( \pm 5^{\circ} \mathrm{C}\right)$. It had been observed that small changes in such operating parameters did not cause drastic changes of the retention time of the peak of interest, tailing factor (NMT 2.0), plate count (NLT
2000), resolution (NLT 2.0) and \%RSD for six replicate injections (NMT 2.0) which were found to be within the acceptance criteria. The results show that the developed method is robust as shown in Tables 8 and 9 .

\section{Forced degradation studies}

In the case of forced degradation studies, aliquots of stock solutions were treated separately with $1 \mathrm{~mL}$ of $2 \mathrm{~N}$ sodium hydroxide (alkaline stability), $1 \mathrm{~mL}$ of $2 \mathrm{~N}$ hydrochloric acid (acid stability), $1 \mathrm{~mL}$ of $20 \%$ hydrogen peroxide (oxidative degradation), photo stability degradation (exposure of drug at 200 watt $\mathrm{h} / \mathrm{m}^{2}$ ), exposure of sample drug solution at $105^{\circ} \mathrm{C}$ for $6 \mathrm{~h}$ (dry heat degradation) and neutral degradation (refluxing with water at $60{ }^{\circ} \mathrm{C}$ for $6 \mathrm{~h}$ ). The stability of such samples was cross-checked with a fresh sample on the particular day of the study. No interference was

Table 4 System precision, intra-day and inter-day results for the developed method

\begin{tabular}{|c|c|c|c|c|c|c|}
\hline \multirow[t]{2}{*}{ Injections } & \multicolumn{2}{|c|}{$\begin{array}{l}\text { Peak response for } \\
\text { system precision }\end{array}$} & \multicolumn{2}{|c|}{$\begin{array}{l}\text { Peak response } \\
\text { for intra-day }\end{array}$} & \multicolumn{2}{|c|}{$\begin{array}{l}\text { Peak response } \\
\text { for inter-day } \\
\end{array}$} \\
\hline & LAM & DOL & LAM & DOL & LAM & DOL \\
\hline 1 & 562,424 & 409,726 & 554,251 & 414,526 & 532,548 & 409,726 \\
\hline 2 & 565,574 & 412,864 & 556,214 & 412,754 & 529,874 & 408,725 \\
\hline 3 & 575,969 & 414,115 & 564,875 & 413,548 & 535,412 & 406,548 \\
\hline 4 & 561,345 & 426,527 & 541,482 & 422,547 & 532,571 & 410,254 \\
\hline 5 & 578,738 & 413,765 & 567,422 & 419,875 & 536,948 & 405,874 \\
\hline 6 & 586,696 & 411,675 & 559,642 & 412,548 & 529,824 & 413,487 \\
\hline AVG & 571,791 & 414,779 & 557,314 & 415,966 & 532,862 & 409,102 \\
\hline S.D & $10,231.19$ & 5971.93 & 9230.43 & 4207.37 & 2882.31 & 2757.89 \\
\hline$\%$ RSD & 1.78 & 1.44 & 1.66 & 1.01 & 0.54 & 0.67 \\
\hline
\end{tabular}


Table 5 Method precision

\begin{tabular}{lll}
\hline $\begin{array}{lll}\text { Sample } \\
\text { preparations }\end{array}$ & \% assay & \\
\cline { 2 - 3 } & Lamivudine & Dolutegravir \\
\hline Sample-1 & 99.7 & 99.6 \\
Sample-2 & 100.1 & 100.1 \\
Sample-3 & 99.6 & 99.7 \\
Sample-4 & 100.8 & 99.2 \\
Sample-5 & 99.5 & 100.4 \\
Sample-6 & 100.3 & 100.0 \\
Average & 100.0 & 99.8 \\
S.D & 0.50 & 0.42 \\
\%RSD & 0.5 & 0.4 \\
\hline
\end{tabular}

exhibited in the HPLC chromatograms of the degraded products at the respective analyte peaks. Hence, the individual analyte peak purity values found to be within the suitable limits; hence, the method was specific and stability-indicating (Tables 10 and 11).

\section{Discussion}

The major aim for the development of the chromatographic method was to urge a reliable technique for the quantification of dolutegravir and lamivudine from the bulk and pharmaceutical dosage form that can be employed also for degradation products. Various conditions of chromatography were applied for the analysis of dolutegravir and lamivudine in both the bulk and pharmaceutical dosage form. The results of analysis obtained was within the suitable limit (not but 2.0). The calibration curves were found to be linear over the concentration range of 14.98 to $91.25 \mu \mathrm{g} / \mathrm{mL}$ for lamivudine and 2.54 to $15.35 \mu \mathrm{g} / \mathrm{mL}$ for dolutegravir. The samples were analysed at $257 \mathrm{~nm}$, the injection volume was $10 \mu \mathrm{L}$ and the separation was done by utilising Inertsil ODS-3 $\mathrm{V},(5 \mu \mathrm{m}, 250 \times 4.6 \mathrm{~mm})$ column. The tailing factor and retention times were computed. The retention time of dolutegravir and lamivudine were found to be 2.169 and $6.367 \mathrm{~min}$, respectively. The proposed column was selected which gave a pointy and symmetrical peak with 1.34 tailing factor and theoretical plates of 7643 for lamivudine and 1.12 tailing factor and theoretical plates of 55924 for dolutegravir. The

Table 6 Results of accuracy study

\begin{tabular}{lll}
\hline$\%$ of target concentration & $\begin{array}{l}\text { Lamivudine } \\
\text { (\% recovery) }\end{array}$ & $\begin{array}{l}\text { Dolutegravir } \\
\text { (\% recovery) }\end{array}$ \\
\hline 50 & 100.16 & 101.48 \\
100 & 99.03 & 99.21 \\
150 & 100.21 & 100.48 \\
Mean \% recovery $(n=3)$ & 99.8 & 100.4 \\
\%RSD & 0.67 & 1.13 \\
\hline
\end{tabular}

At each \% level mean \% recovery in the acceptable limit of 98.0 to $102.0 \%$
Table 7 Intermediate precision results

\begin{tabular}{lll}
\hline \multirow{2}{*}{$\begin{array}{l}\text { Sample } \\
\text { preparations }\end{array}$} & \% assay & \\
\cline { 2 - 3 } & Lamivudine & Dolutegravir \\
\hline Sample-1 & 98.9 & 99.2 \\
Sample-2 & 100.1 & 100.0 \\
Sample-3 & 99.4 & 99.6 \\
Sample-4 & 100.2 & 98.9 \\
Sample-5 & 99.7 & 100.1 \\
Sample-6 & 100.4 & 99.9 \\
AVG & 99.8 & 99.6 \\
S.D & 0.56 & 0.48 \\
\%RSD & 0.6 & 0.5 \\
\hline
\end{tabular}

resolution between dolutegravir and lamivudine is 22.51. The linearity of the method was confirmed statistically. The RSD values obtained for the accuracy and precision studies were but $2.0 \%$ which proved that the developed analytical method was accurate and precise.

It was concluded from the forced degradation studies that all the degradant peaks exhibited during the degradation were well resolved from major drugs, i.e. dolutegravir and lamivudine, and therefore the peak purity was passed, i.e. purity angle was less than purity threshold as per waters Empower-3 software. Therefore, the method is established to be stability-indicating.

\section{Conclusion}

The developed chromatographic method is simple, accurate and selective as well as proved to be stabilityindicating for the simultaneous estimation of dolutegravir and lamivudine in the bulk and pharmaceutical dosage form. Preparation of sample is straightforward, the analysis time is short and therefore the elution is by isocratic method. To our present knowledge, no

Table 8 Robustness Results for Lamivudine

\begin{tabular}{|c|c|c|c|c|c|c|c|}
\hline S. No. & Parameter & $\begin{array}{l}\text { As such } \\
\text { method }\end{array}$ & Used & $\begin{array}{l}\text { \%RSD } \\
\text { for peak } \\
\text { area } \\
(\boldsymbol{n}=6)\end{array}$ & $\begin{array}{l}\text { Average } \\
\text { retention } \\
\text { time }\end{array}$ & $\begin{array}{l}\text { Plate } \\
\text { count }\end{array}$ & $\begin{array}{l}\text { Tailing } \\
\text { factor }\end{array}$ \\
\hline \multirow[t]{3}{*}{1} & \multirow{3}{*}{$\begin{array}{l}\text { Flow rate } \\
( \pm 0.1 \mathrm{~mL} / \\
\text { min })\end{array}$} & \multirow[t]{3}{*}{$\begin{array}{l}1.0 \mathrm{~mL} / \\
\min \end{array}$} & $\begin{array}{l}0.9 \mathrm{~mL} / \\
\min \end{array}$ & 0.2 & 2.374 & 9457 & 1.35 \\
\hline & & & $\begin{array}{l}1.0 \mathrm{~mL} / \\
\min \end{array}$ & 0.7 & 2.169 & 7651 & 1.32 \\
\hline & & & $\begin{array}{l}1.1 \mathrm{~mL} / \\
\min \end{array}$ & 1.0 & 2.152 & 9145 & 1.30 \\
\hline \multirow[t]{3}{*}{2} & \multirow{3}{*}{$\begin{array}{l}\text { Column } \\
\text { temperature } \\
\left( \pm 5^{\circ} \mathrm{C}\right)\end{array}$} & \multirow[t]{3}{*}{$30^{\circ} \mathrm{C}$} & $25^{\circ} \mathrm{C}$ & 0.3 & 2.134 & 8640 & 1.25 \\
\hline & & & $30^{\circ} \mathrm{C}$ & 0.7 & 2.169 & 7657 & 1.31 \\
\hline & & & $35^{\circ} \mathrm{C}$ & 1.5 & 2.150 & 9128 & 1.33 \\
\hline \multirow[t]{3}{*}{3} & \multirow{3}{*}{$\begin{array}{l}\text { Mobile } \\
\text { phase } \\
\text { composition }\end{array}$} & \multirow{3}{*}{$\begin{array}{l}\text { Buffer: } \\
\text { ACN: } \\
\text { Methanol, } \\
\text { 55:20:30\% } \\
\text { v/v }\end{array}$} & $55: 25: 25$ & 0.5 & 2.136 & 8648 & 1.30 \\
\hline & & & $55: 20: 30$ & 0.7 & 2.169 & 7653 & 1.31 \\
\hline & & & $55: 15: 35$ & 0.9 & 2.164 & 8475 & 1.33 \\
\hline
\end{tabular}


Table 9 Robustness results for dolutegravir

\begin{tabular}{|c|c|c|c|c|c|c|c|c|}
\hline S. No. & Parameter & As such method & Used & $\begin{array}{l}\text { \%RSD for peak } \\
\text { area }(\boldsymbol{n}=6)\end{array}$ & $\begin{array}{l}\text { Average } \\
\text { retention time }\end{array}$ & $\begin{array}{l}\text { Plate } \\
\text { count }\end{array}$ & $\begin{array}{l}\text { Tailing } \\
\text { factor }\end{array}$ & Resolution \\
\hline \multirow[t]{3}{*}{1} & \multirow[t]{3}{*}{ Flow rate $( \pm 0.1 \mathrm{~mL} / \mathrm{min})$} & \multirow[t]{3}{*}{$1.0 \mathrm{~mL} / \mathrm{min}$} & $0.9 \mathrm{~mL} / \mathrm{min}$ & 0.8 & 6.687 & 50185 & 1.12 & 23.47 \\
\hline & & & $1.0 \mathrm{~mL} / \mathrm{min}$ & 0.9 & 6.367 & 55945 & 1.14 & 22.51 \\
\hline & & & $1.1 \mathrm{~mL} / \mathrm{min}$ & 1.2 & 6.354 & 53434 & 1.06 & 21.34 \\
\hline \multirow[t]{3}{*}{2} & \multirow[t]{3}{*}{ Column temperature $\left( \pm 5^{\circ} \mathrm{C}\right)$} & \multirow[t]{3}{*}{$30^{\circ} \mathrm{C}$} & $25^{\circ} \mathrm{C}$ & 0.5 & 6.321 & 52290 & 1.11 & 22.49 \\
\hline & & & $30^{\circ} \mathrm{C}$ & 0.9 & 6.367 & 55945 & 1.16 & 22.51 \\
\hline & & & $35^{\circ} \mathrm{C}$ & 1.5 & 6.353 & 53457 & 1.07 & 22.37 \\
\hline \multirow[t]{3}{*}{3} & \multirow[t]{3}{*}{ Mobile phase composition } & \multirow[t]{3}{*}{ Buffer:ACN:Methanol, 55:20:30\% v/v } & $55: 25: 25$ & 0.7 & 6.322 & 52235 & 1.08 & 22.48 \\
\hline & & & $55: 20: 30$ & 0.9 & 6.367 & 55985 & 1.13 & 22.51 \\
\hline & & & $55: 15: 35$ & 1.2 & 6.364 & 51769 & 1.04 & 22.58 \\
\hline
\end{tabular}

Table 10 Forced degradation study results for lamivudine

\begin{tabular}{|c|c|c|c|c|c|c|}
\hline$\overline{\mathrm{S} . \mathrm{NO}}$ & Sample name & $\%$ assay & $\%$ degradation & Purity angle & Purity threshold & Purity flag \\
\hline 1 & Controlled sample & 100.1 & -- & 0.310 & 1.375 & No \\
\hline 2 & Acid degradation & 95.1 & 5.0 & 0.325 & 0.463 & No \\
\hline 3 & Alkaline degradation & 96.9 & 3.2 & 0.575 & 1.081 & No \\
\hline 4 & Peroxide degradation & 94.8 & 5.3 & 1.612 & 2.175 & No \\
\hline 5 & Thermal degradation & 98.3 & 1.8 & 0.268 & 0.294 & No \\
\hline 6 & UV degradation & 99.7 & 0.4 & 0.318 & 0.335 & No \\
\hline 7 & Water degradation & 98.4 & 1.7 & 0.264 & 0.298 & No \\
\hline
\end{tabular}

Table 11 Forced degradation study results for dolutegravir

\begin{tabular}{lllllll}
\hline S. No & Sample name & \% assay & \% degradation & Purity angle & Purity threshold & Purity flag \\
\hline 1 & Controlled sample & 99.9 & - & 0.122 & 0.378 & No \\
2 & Acid degradation & 95.1 & 4.8 & 0.397 & 0.475 & No \\
3 & Alkaline degradation & 96.3 & 3.6 & 0.761 & 1.199 & No \\
4 & Peroxide degradation & 91.4 & 8.5 & 0.154 & 0.498 & No \\
5 & Thermal degradation & 97.6 & 2.3 & 0.397 & 0.492 & No \\
6 & UV degradation & 98.1 & 1.8 & 0.454 & 0.458 & No \\
7 & Water degradation & 98.6 & 1.3 & & & \\
\hline
\end{tabular}


attempts have yet been made to estimate this multidrug mixture by the stability-indicating analytical procedure. All the active ingredients were profitably resolved with good resolution and quantified. Hence, the suggested validated stability-indicating method was successfully employed to work out dolutegravir and lamivudine in the bulk and pharmaceutical dosage form. It is going to be extended to review for its estimation in plasma and other biological fluids and may even be employed for quality control stability sample estimation and in cleaning method analysis during cleaning validation.

\section{Abbreviations \\ DOL: Dolutegravir; HPLC: High-performance liquid chromatography; ICH: International Conference on Harmonisation; LAM: Lamivudine; LOD: Limit of detection; LOQ: Limit of quantification; NMT: Not more than; NLT: Not less than; RSD: Relative standard deviation}

\section{Acknowledgements}

We are thankful for all those who have supported us during this research work.

\section{Authors' contributions}

NK conducted the literature study and designed, developed and validated the new RP-HPLC method. NK and SN compiled, analyzed and interpreted the data. NK and SN wrote the manuscript. All authors read and approved the final manuscript.

\section{Funding}

There is no funding source for this project.

\section{Availability of data and materials}

The datasets used and/or analysed during the current study are available from the corresponding author on reasonable request

\section{Ethics approval and consent to participate}

Not applicable

\section{Consent for publication}

Not applicable

\section{Competing interests}

The authors declare that they have no competing interests.

\section{Author details}

${ }^{1}$ Department of Pharmaceutical Sciences, Acharya Nagarjuna University, Nagarjunanagar, Guntur, Andhra Pradesh 522510, India. ${ }^{2}$ Department of Chemistry, Acharya Nagarjuna University, Nagarjunanagar, Guntur, Andhra Pradesh 522510, India.

Received: 28 March 2020 Accepted: 20 July 2020

Published online: 28 July 2020

\section{References}

1. http://www.drugbank.ca/drugs/DB00709.

2. http://www.drugbank.ca/drugs/DB08930.

3. https://www.gsksource.com/pharma/content/dam/GlaxoSmithKline/US/en/ Prescribing_Information/Dovato/pdf/DOVATO-PI-PIL.PDF.

4. ViiV Healthcare (2019) D-ovato (dolutegravir and lamivudine). https: //www. centerwatch.com. Accessed 7 Aug 2019

5. Anantha Kumar D, Srinivasa Rao G, JVLN SR (2010) Simultaneous determination of lamivudine, zidovudine and abacavir in tablet dosage form by RP-HPLC method. E J of Chem 7(1):180-184. https://doi.org/10. 1155/2010/473798

6. Ashok G, Mondal DS (2018) Development and validation of stability indicating method for the simultaneous estimation of batcaver sulphate, lamivudine and dolutegravir sodium in pharmaceutical dosage forms by RPHPLC Saudi. J Med Pharm Sci 4:289-296. https://doi.org/10.21276/sjmps. 2018.4.2.18
7. Khaleel N, SK AR (2015) A validated stability indicating RP-HPLC method for simultaneous determination of abacavir, lamivudine and dolutegravir in bulk and pharmaceutical dosage form. W J of Pharm. Res 4(7):1453-1476

8. Mallikarjuna Rao N, Gowri Sankar D (2015) Development and validation of stability-indicating HPLC method for simultaneous determination of lamivudine, tenofovir and dolutegravir in bulk and their tablet dosage form. Future J Pharm Sci 1:73-77

9. Vijayalakshmi R, Kalyani P, Sandya P, Dhanaraju MD (2013) Method development and validation of a reverse phase liquid chromatographic method for simultaneous determination of lamivudine and abacavir sulphate in tablets. A. J. of Phytomed and Clin. Therapeutics. 1(2):208-214

10. Raja T, Lakshmana Rao A (2011) Development and validation of RP-HPLC method for estimation of abacavir, lamivudine and zidovudine in pharmaceutical dosage form. Int. J of Pharm Tech Res. 3(2):852-857

11. Anil Yadav N, Mangamma K, Mani Kumar G (2013) Analytical method development and validation by RP-HPLC for the simultaneous estimation of abacavir sulphate and lamivudine in tablet dosage forms. Int. J. of Pharm, Chem. Bio Sci. 3(3):538-545

12. Mastanamma S, Jyothi JA, Saidulu P (2018) Development and validation of RP-HPLC method for the simultaneous estimation of lamivudine, tenofovir alafenamide and dolutegravir bulk and their combined dosage form. Pharm Methods 9:49-55

13. Sudha T, Ravi Kumar VR, Hemalatha PV (2008) RP-HPLC method for simultaneous estimation of Lamivudine and Abacavir sulfate in tablet form. Int. J. on Pharm. Biomed. Res. 1(4):108-113

14. Pal N, Avanapu SR, Ravikumar P (2016) Simultaneous HPLC method development and validation for estimation of Lamivudine, Abacavir and Dolutegravir in combined dosage form with their stability studies. Asian J Chem 28:273-276

15. Kenney BK, Wring AS, Carr MR, Wells NG, Dunn AJ (2000) Simultaneous determination of zidovudine and lamivudine in human serum using HPLC with tandem mass spectrometry. J. Pharm. Biomed. Anal 22:967-983

16. Pereira SA, Kenney BK, Cohen SM, Hall EJ, Eron JJ, Tidwell RR, Dunn AJ (2000) Simultaneous determination of lamivudine and zidovudine concentrations in human seminal plasma using HPLC and tandem mass spectrometry. J Chrom. B. 742:173-183

17. Bennetto-Hood C, Tabolt G, Paul MS, Edward P (2015) A sensitive HPLC-MS/ MS method for the determination of dolutegravir in human plasma. J Chrom. B. Analyt Tech. Biomed. Life Sci 15:225-232

18. Sparidans WR, Hoetelmans WMR, Beijnen HJ (2001) Liquid chromatography assay for simultaneous determination of abacavir and mycophenolic acid in human plasma using dual spectrophotometric detection. J. of Chrom. B. 750:155-161

19. Vikram Singh A, Nath LK, Pani NR (2011) Development and validation of analytical method for estimation of lamivudine in rabbit plasma. J Pharm Anal 1:251-257

20. Sudha T, Ravikumar VR, Hemalatha PV (2010) Validated HPTLC method for simultaneous determination of lamivudine and abacavir sulfate in tablet dosage form. Int. J. Pharm Sci and Res. 1(11):101-111

21. Bhavar GB, Pekamwar SS, Aher KB (2016) High-performance liquid chromatographic and high-performance thin-layer chromatographic method for the quantitative estimation of dolutegravir sodium in bulk drug and pharmaceutical dosage form. Sci Pharm 84:305-320

22. Deepali G, Elvis M (2010) UV spectrophotometric method for assay of the anti-retroviral agent lamivudine in active pharmaceutical ingredient and in its tablet formulation. J Young Pharm JYP 2:417-419

23. Balasaheb BG, Balasahen AK, Subhash TR, Jijabapu K (2015) Development and validation of UV spectrophotometric method for estimation of dolutegravir sodium in tablet dosage form. Malaysian J Anal Chem 19:1156-1163

24. Madu KC, Ukoha PO, Attama AA (2011) Spectrophotometric determination of lamivudine using chloranilic acid and 2,3-dichloro-5,6-dicyano-1,4benzoquinone (DDQ). Am J Anal Chem 2:849-856

25. Sravan Kumar Reddy G, Ashutosh Kumar S, Raj Kumar V (2014) A new, simple, sensitive, accurate and rapid analytical method development and validation for simultaneous estimation of lamivudine, abacavir and zidovudine in tablet dosage form by using UPLC. Int. J. Pharm Sci and Res. 5(9):3852-3863

26. Harmonised Tripartite Guideline ICH (2005) Validation of Analytical Procedures: Text and Methodology Q2(R1) Current Step 4 Version, November

\section{Publisher's Note}

Springer Nature remains neutral with regard to jurisdictional claims in published maps and institutional affiliations. 